Arhe XVIII, 35/2021

UDK 1 Heidegger $M$.

1 Baumgarten A.G.

$11 / 12: 111.852$

DOI https://doi.org/10.19090/arhe.2021.35.183-201

Originalni naučni rad

Original Scientific Article

\author{
UNA POPOVIĆ \\ Univerzitet u Novom Sadu, Filozofski fakultet
}

\title{
HAJDEGER O BAUMGARTENU
}

Sažetak: Rad je posvećen tumačenju nekoliko Hajdegerovih komentara o Baumgartenu iz predavanja Pitanje o stvari. Analiza pokazuje da Hajdeger u vezi sa Baumgartenom ističe odnos metafizike i estetike, te da zasnivanje estetike vidi kao implicitno vođeno novovekovnim razumevanjem bivstvujućeg kao stvari i predmeta čulnog opažanja. Rezultat analize ukazuje na važno mesto kritike Baumgartena u pogledu projekta prevladavanja estetike, te omogućava dublje razumevanje nekih od osnovnih postavki Hajdegerove filozofije umetnosti.

Ključne reči: Hajdeger, Baumgarten, estetika, stvar, prevladavanje

Misao osnivača estetike, Aleksandra G. Baumgartena (A. G. Baumgarten), u velikoj meri zanemarena je $\mathrm{u}$ istoriji estetike i filozofije. Iako je ovaj mislilac po pravilu prepoznat kao onaj koji je osmislio kako disciplinu, tako i njen naziv, njegovo centralno delo - dvotomna Estetika sa latinskog jezika po prvi put je u celini prevedeno tek 2007. godine (na nemački). Navedeno jasno govori o tome da su i interpretacije njegove misli oskudne i rezervisane na tek par zainteresovanih istraživača, kao i da je srž prve estetike, izuzev u osnovnim crtama, ostala mahom nepoznata široj filozofskoj javnosti.

Hajdegerov (M. Heidegger) odnos prema estetici i umetnosti, pak, predstavlja jedno od najvažnijih pitanja njegove pozne filozofije. Imajući u vidu da se Hajdeger, tokom celokupnog svog misaonog delovanja, intenzivno bavio kritičkim tumačenjem tradicije filozofije, a posebno $\mathrm{s}$

\footnotetext{
${ }^{1}$ E-mail adresa autorke: unapopovic@ff.uns.ac.rs
} 
obzirom na njegovu tezu o neophodnosti prevladavanja estetike - odnosno, o potrebi za uspostavljanjem novog filozofskog odnosa prema umetnosti, moglo bi se očekivati da će i Baumgarten biti jedan od mislilaca kojima se Hajdeger naročito bavi. To, međutim, nije tako: Baumgarten ne zauzima prominentno mesto u Hajdegerovoj kritici tradicije estetike, niti mu Hajdeger tematski posvećuje bilo koje od svojih predavanja ili tekstova. Na prvi pogled, dakle, čini se da Baumgarten za Hajdegera ostaje u senci koliko i za (skoro) sve druge istraživače istorije estetike.

U ovom radu odlučili smo se da takvu sliku Hajdegerovog odnosa prema Baumgartenu bar delimično dovedemo u pitanje. Hajdeger, naime, ipak govori o osnivaču estetike; on to čini uzgred i šturo, skoro neprimetno, u samo par komentara. Uprkos tome, smatramo da tih nekoliko detalja ima specifičnu težinu, te da njihovim razmatranjem možemo dobiti interesantne uvide u osobeni odnos Hajdegera prema umetnosti u njenoj tradicionalnoj i savremenoj filozofskoj obradi. Redovi koji slede posvećeni su tom zadatku.

\section{BAUMGARTEN, METAFIZIKA I PITANJE O STVARI}

Nekoliko Hajdegerovih eksplicitnih komentara o Baumgartenu zatičemo u predavanjima Pitanje o stvari, koja je on održao u zimskom semestru 1935/36. godine na Univerzitetu u Frajburgu u Brajsgau. Predavanja su, bar načelno, posvećena tumačenju Kanta (I. Kant), a s obzirom na njihovo vodeće i tematsko pitanje šta je stvar, ona odgovaraju okviru predavanja Uvod u metafiziku, održanim u letnjem semestru 1935. godine na istom univerzitetu. Ova dva predavanja, kao i spis Izvor umetničkog dela iz istog perioda, uzimamo kao pozadinski horizont i okvir koji bi trebalo da usmere tumačenje Hajdegerovih stavova o Baumgartenu. Naime, pošto Baumgarten nije centralna tema, već se komentari o njemu pojavljuju kao deo šireg Hajdegerovog istraživanja, njega u tumačenju moramo uvažiti kao specifičnu optiku sagledavanja osnivača estetike.

U prvom redu tim smeramo na vezu estetike i metafizike, koja kod Hajdegera dalje vodi pomenutoj tezi o prevladavanju estetike. Baumgarten se, naime, u Pitanju o stvari pominje najpre kao metafizičar, a njegova 
estetika potom se postavlja kao metafizička: problem metafizike stoga je perspektiva iz koje treba tumačiti Baumgartena u Hajdegerovom zahvatu. ${ }^{2} \mathrm{U}$ Hajdegerovoj upotrebi pojam metafizike ima poseban smisao i prevashodno se odnosi na načelni horizont poimanja bivstvovanja karakterističan za tradiciju filozofije, bez obzira na razlike između epoha i pojedinačnih filozofskih disciplina. Pod metafizikom, grubo rečeno, treba razumeti sve ono što je u filozofskom smislu nastalo na osnovu tradicionalnog načina postavljanja i odgovaranja na pitanje o bivstvovanju, koje je, kako je poznato, istovremeno i ključno pitanje Hajdegerove misli. Otuda u analize uvodimo i Uvod u metafiziku: reč je, naime, o tome da je u oba navedena predavanja centralno područje ispitivanja zapravo sama metafizika, osobeno fokusirana preko pitanja o stvari.

Kada je reč o predavanjima Pitanje o stvari, na metafiziku nas upućuje već i pomenuto vodeće i tematsko njihovo pitanje - šta je stvar? Razlog tome je Hajdegerov stav da je za tradicionalnu metafiziku, odnosno za njen način postavljanja pitanja i odgovaranja na pitanje o bivstvovanju, karakteristično upravo fokusiranje tog pitanja i njegovih odgovora na bivstvujuće - a ne na bivstvovanje; u ovom predavanju stvar se ističe kao ključni oblik razumevanja metafizički odlikovanog bivstvujućeg. Isti pojam upućuje i na vezu metafizike i estetike, budući da Hajdeger u programskom spisu svoje filozofije umetnosti iz istog perioda, Izvoru umetničkog dela (1935-1936.), ispitivanje suštine umetnosti započinje upravo razračunavanjem sa tradicionalnim pojmom stvari koji, po njegovom sudu, onemogućava ispravno razumevanje umetničkog dela. ${ }^{3}$

Prema Hajdegeru, tradicionalna metafizika pitanje o bivstvovanju svodi na pitanje o bivstvujućem, čineći time ontološku diferenciju nevidljivom. U takvom postupanju, međutim, metafizika sopstveni način pitanja o bivstvovanju sprovodi fokusiranjem jednog tipa bivstvujućih, kao odlikovanog i glavnog slučaja na osnovu kog se, dalje, izvode teze koje bi trebalo da važe za sva bivstvujuća. Taj odabrani tip ili domen bivstvujućih

2 Uр. Хајдегер, М., Питање о ствари. О Кантовом учењу $о$ трансиенденталним начелима, Плато, Београд, 2009, str. 109.

${ }^{3}$ Uр. Хајдегер, М., „Извор уметничког дела”, у: Шумски путеви, Плато, Београд, 2000, str. 8, 11-13. 
upravo su stvari, odnosno ona bivstvujuća koja nisu čovek. ${ }^{4}$ Kako je dobro poznato, u svom prvom glavnom delu, Bivstvovanje i vreme, Hajdeger će nastojati da na takav gest tradicije odgovori inverznim gestom izbora čoveka kao tubivstvovanja za ono bivstvujuće kojim će bitno biti određena izgradnja njegove nove fundamentalne ontologije.

Otkuda, onda, postavljanje pitanja o stvari - a ne o čoveku tridesetih godina u Hajdegerovoj misli? Kako treba razumeti ovaj povratak pitanja o stvari, ukoliko je ono, prema Hajdegerovom sopstvenom sudu, celokupnu tradiciju odvelo na pogrešan trag? $\mathrm{Na}$ ova pitanja možemo odgovoriti na dva načina: jednom $\mathrm{s}$ obzirom na opšte tendencije Hajdegerove misli, a drugi put s obzirom na period kome pripadaju predavanja Pitanje o stvari, a koji je specifično formativan za Hajdegerovu filozofiju.

Kada je reč o prvoj perspektivi, povratak pitanja o stvari možemo vezati za Hajdegerovu načelnu nameru da se razračuna sa tradicijom filozofije, a naročito sa onim njenim momentima koji neprimetno ostaju na snazi i danas. Napor razračunavanja sa njom najpre je poznat pod zastavom pojma destrukcije (pre svega u ranim radovima), a potom, u poznim radovima, i preko formulacije prevladavanje metafizike. ${ }^{5}$ Primera radi, u predavanju Stvar iz 1950. godine Hajdeger kaže: „Ono stvarno što je tipično za stvar ostaje skriveno, zaboravljeno. Suština stvari nikad ne izlazi na videlo, to jest o njoj se nikad ne zbori". ${ }^{6}$

Reč je o Hajdegerovom uverenju da se tradicija ne može prosto negirati i da se sa njenim uticajem ne može lako završiti, pukim uspostavljanjem neke kritičke distance. Naprotiv, puko negiranje tradicije bi je zapravo osnažilo, jer ona se za Hajdegera ne vezuje prosto za pojedinačne stavove i pozicije velikih filozofa, već pre za način mišljenja koji svima

${ }^{4}$ Up. Ibid., str. 11, 18; Heidegger, M., Bitak $i$ vrijeme, Naprijed, Zagreb, 1988, str. $13,16$.

${ }^{5}$ Up. Heidegger, M., Prilozi filozofiji. Iz dogođaja, Naklada Breza, Zagreb, 2008, str. 149.

${ }^{6}$ Хајдегер, М., „Ствар”, у: Предавања и расправе, Плато, Београд, 1999, str. 135. 
njima stoji u osnovi, a koji on označava pojmom metafizike. ${ }^{7} \mathrm{U}$ tom smislu, pokušaj filozofskog mišljenja koji bi bio oslobođen od tradicije mora sa istom da se razračuna iznutra, upravo tako što će detektovati taj način mišljenja karakterističan za tradiciju, a koji se može - što je i slučaj pokazati u različitim oblicima i artikulacijama. Stoga i pitanje o stvari u Hajdegerovoj misli tridesetih godina pripada istom tom projektu - ono je jedna od karika prevladavanja metafizike.

Sa druge strane, Hajdegerova filozofija tridesetih godina specifična je po tome što ovaj period predstavlja prve njegove korake od rane filozofije i fundamentalne ontologije ka poznoj misli u njenom punom smislu. Naime, kao što je poznato, Hajdeger svoje prvo glavno delo nije dovršio, smatrajući da je put koji je tu odabrao ipak manjkav za namere koje je želeo da ostvari. Otuda se upravo tridesetih godina odvija ponovni pokušaj da se pitanje o bivstvovanju postavi na adekvatan način: 1969. godine, na seminaru u Le Toru, Hajdeger jasno formuliše razliku ta dva svoja pristupa, kao razliku u postavljanju pitanja o smislu bivstvovanja i pitanja o istini bivstvovanja. ${ }^{8}$ Štaviše, sam Hajdeger o ovom trusnom periodu svoje misli govori kao o okretu (Kehre), time dajući jasne naznake da je tridesetih godina na delu nešto sasvim novo.

Pitanje o stvari, kao i Uvod u metafiziku - predavanja koja, već smo pokazali, spadaju u projekat prevladavanja metafizike - tako treba sagledati i naspram okreta, odnosno nedovršenog projekta Bivstvovanja i vremena. U Uvodu u metafiziku Hajdeger čak i otvoreno govori o tome, upućujući nas da ova predavanja čitamo kao svojevrsni nastavak, iako nesumnjivo ne i kao dovršenje svog prvog glavnog dela. ${ }^{9}$ U Pitanju o stvari, međutim, on na rane pozicije upućuje više posredno, ali time ne manje značajno: naime, ovde on razrađuje pitanje kategorijalnosti, odnosno pitanje načina na koji je tradicija filozofije razumela bivstvujuća (a time posredno i bivstvovanje) kao kategorijalna.

${ }^{7}$ Up. Kockelmans, J. J., On the truth of Being, Reflections on Heidegger's later philosophy, Indiana University Press, Bloomington, 1984, str. 171.

${ }^{8}$ Up. Heidegger, M., „Seminar in Le Thor 1969”, in: Seminare, GA 15, Vittorio Klostermann, Frankfurt am Mein, 1986, str. 335.

${ }^{9}$ Up. Хајдегер, М., Увод у метафизику, Еидос, Врњачка Бања, 1997, str. 24-25. 
Pitanje kategorijalnosti je naglašeno u Bivstvovanju $i$ vremenu, gde je ono $\mathrm{i}$ suprotstavljeno pitanju egzistencijalnosti. ${ }^{10}$ Ipak, shodno Hajdegerovim namerama $\mathrm{u}$ tom delu, tematsku obradu ponajpre dobija egzistencijalnost, dok kategorijalnost ostaje u drugom planu. Taj propust se, čini se, sada nadomešta otvaranjem pitanja o stvari, a tematizacija kategorijalnosti biće prisutna u Hajdegerovim radovima praktično do samog kraja njegovog života i rada. Ipak, ovde moramo postojano imati na umu da se to pitanje sada razmatra sa izmenjenih pozicija: primera radi, ono se ne svodi samo na pitanje o stvari, već i na pitanje o tvorevini, kao i na pitanje o umetničkom delu; dalje to znači tematizaciju tehnike, nauke, umetnosti i prostora. ${ }^{11}$

Slično važi i za već usvojeni zaključak da pitanje o stvari, odnosno pitanje kategorijalnosti, spada u prevladavanje metafizike. Naime, iako smo prethodno naglasili da prevladavanje metafizike podrazumeva Hajdegerov odnos prema tradiciji i pokušaj njene imanentne kritike, sada moramo istaći da ono uvek podrazumeva i korak unapred, dalje od tih pozicija, odnosno otvaranje misaonog horizonta koji ne bi bio tradicionalni i metafizički. Dakle, reč je o tome da je prevladavanje uvek otvoreno u dva smera, ka prošlom i tradicionalnom i ka budućem i novom istovremeno; oba se, naravno, ukrštaju u sadašnjosti.

Sva navedena promišljanja neophodna su nam da bismo na ispravan način razumeli Hajdegerove komentare o Baumgartenu. Naime, kako je pomenuto, osnivač estetike nije samo zasnovao ovu oblast filozofskog promišljanja kao specifičnu (fillozofsku) nauku, već joj je čak dao i ime. Hajdeger je, svakako, upoznat sa ovim činjenicama i pominje ih. Ipak, njegovi komentari o Baumgartenu nisu uže fokusirani na estetiku, kako bi se dalo očekivati, već upravo na metafiziku. Štaviše, Hajdeger o Baumgartenu ne govori u bilo kom kontekstu tematizacije metafizike, već upravo $\mathrm{s}$ obzirom na problem stvari: u pitanju je naznaka koja upućuje ka smislu veze prevladavanja metafizike i prevladavanja estetike, a koja se može razumeti upravo spram zasnivanja estetike. $\mathrm{O}$ čemu je tačno reč, razmotrićemo u redovima koji slede.

\footnotetext{
${ }^{10}$ Up. Heidegger, M., Bitak i vrijeme, str. 49.

${ }^{11}$ Up. Хајдегер, М., Увод у метафизику, str. 73.
} 


\section{BAUMGARTENOVA METAFIZIKA I PROBLEM ESTETIKE}

Nekoliko reči koje nam Hajdeger ostavlja o Baumgartenu u predavanjima Pitanje o stvari situirane su u prvi deo drugog dela predavanja (Kantov način da se pita o stvari), pod naslovom „Povesno tlo na kojem počiva Kantova Kritika čistog uma". Dakle, o Baumgartenu Hajdeger govori s obzirom na razmatranje pretpostavki Kantovog mišljenja, u smislu ocrtavanja filozofske klime i ideja koje Kantu prethode i određuju ga. Pri tome je, svakako, centralna tema novovekovna metafizika, i upravo s obzirom na to Hajdeger tvrdi: „Baumgartenov udžbenik nam posreduje oblik uobičajene metafizike XVIII veka, oblik koji je Kantu bio neposredno pred očima, i koji je, konačno, iznudio ono delo kojim je Kant tu metafiziku oslobodio okova i iznova postavio pitanje o metafizici". ${ }^{12}$

Navedeni citat iznenađuje, i to u dva pogleda. Najpre, kao što smo već pomenuli, Baumgarten se ovde postavlja pre kao metafizičar, nego kao osnivač estetike. Sa jedne strane, vrlo je neobično što Hajdeger tako malo govori o estetici u vezi sa Baumgartenom; ipak, za to postoje osobeni razlozi, o čemu ćemo govoriti kasnije. Sa druge strane, važno je primetiti da je upravo Metafizika Baumgartenova za njegovog života bila njegovo najpoznatije i najčitanije delo, što Hajdeger na datom mestu očigledno uvažava. Razlozi za to su mnogobrojni, od koji je jedan izvesno i činjenica da njegova obimna i dvotomna Estetika za života nije dovršena, dok je, pak, Metafizika to bila. ${ }^{13}$ Razmatrati Baumgartena kao odlikovanog metafizičara XVIII veka, dakle, nije pogrešno, ali otvorenim ostaje pitanje zbog čega se Hajdeger upravo na to odlučio.

12 Хајдегер, М., Питање о ствари, str. 109. Pri tome Hajdeger misli na Baumgartenovo delo Metafizika: Baumgarten, A. G., Metaphysica. Metaphysik, Frommann-Holzboog Verlag, Stuttgart, 2011.

${ }^{13}$ Delo je objavljeno 1739. godine. Up. Poppe, B., Alexander Gottlieb Baumgarten. Seine Bedeutung und Stellung in der Leibniz-Wollfische Philosophie und seine Beziehungen zu Kant, Buchdruckerei Robert Noske, Borna-Leipzig, 1907, str. 1314; Mirbach, D., 'Einführung zur fragmentarischen Ganzheit von Alexander Gottlieb Baumgartens Aesthetica $(1750 / 1758)^{\prime}$, in: Baumgarten, A. G., Ästhetik I, Felix Meiner Verlag, Hamburg, 2007, str. XX-XXI. 
Drugo što iznenađuje $u$ ovom citatu je implicitna sugestija da Kantovo novo postavljanje pitanja o metafizici i njegov otpor novovekovnim njenim okvirima treba sameravati upravo spram Baumgartena - a ne, na primer, spram Volfa (C. Wolff), ili Lajbnica (G. W. Leibniz), dvojice mislilaca na čijem tragu radi Baumgarten. ${ }^{14}$ Ovde treba biti pažljiv: Hajdeger ne tvrdi da je Kant svoje nove pozicije iskovao čitajući Baumgartena ili u neposrednom dijalogu sa njegovim mišljenjem, zanemarujući ostale. ${ }^{15}$ Naprotiv, on tvrdi da Baumgartenova metafizika predstavlja oblik uobičajene metafizike XVIII veka, te da Kant reaguje upravo spram tog uobičajenog oblika novovekovne metafizike, a ne spram Baumgartena lično.

Ako tako čitamo, ispostavlja se da je Baumgarten ovde izdvojen zbog toga što njegova metafizika u najkristalnijem obliku predstavlja ono što je inače tipično i karakteristično za novovekovnu metafiziku, te je, stoga, i razumljivo zbog čega bi on bio odabran kao centralna figura. Dakle, ovde nije reč o samom Baumgartenu, već on, u izvesnom smislu, predstavlja zastupnika svih metafizičara svoje epohe. Ipak, uprkos tome, ovaj Hajdegerov izbor čudi - zašto je Baumgarten ne samo metafizičar, već i glavni metafizičar svog doba?

U kratkoj analizi koja sledi nakon navedenog citata Hajdeger zapravo ne tumači direktno Baumgartenovu Metafiziku, već upravo osnovne crte ovog oblika uobičajene metafizike XVIII veka koji ona predstavlja i zastupa. On to čini s obzirom na tri značajna pitanja: 1) kako novovekovna metafizika određuje sopstveni pojam, 2) kako je unutar novovekovne metafizike pojmljena suština istine, čiji je sama metafizika najviši izraz, te 3 ) kakva je unutrašnja građa ove metafizike ${ }^{16}$ Odgovarajući na ova pitanja, Hajdeger se zaista i osvrće na pasaže i definicije iz Baumgartenove Metafizike, no oni, po našem sudu, predstavljaju samo ilustraciju nečeg što

\footnotetext{
14 Štaviše, nešto kasnije u tekstu, Hajdeger iznova upućuje na Baumgartena kao centralnu ličnost, ali u pogledu na Kantov odnos prema logici. Napominjući da je Kant držao predavanja po Majerovom (G. F. Meier) udžbeniku, Kant ne propušta da istakne da je Majer bio Baumgartenov učenik, sugerišući time jedinstvenu liniju ove logike i novovekovne metafizike. Up. Хајдегер, М., Питање о ствари, str. 142.

${ }^{15}$ Iako Hajdeger tvrdi i sledeće: „U osnov svog predavanja iz metafizike Kant je stavio već spomenuti udžbenik Aleksandera Baumgartena”. Ibid., str. 108.

${ }^{16}$ Up. Ibid., str. 109.
} 
samog Baumgartena prevazilazi; ova analiza nije minuciozna interpretacija Baumgartena.

Rezultat analize je, stoga, važeći za celokupno novovekovlje, a ne samo za Baumgartena: ovakva metafizika zasnovana je na primatu uma, čija unutrašnja zakonitost unapred odlučuje o „bitku bića, stvarovitosti stvari”. ${ }^{17}$ U sličnom duhu, suština istine razumljena je tako da ona ,za svaki čovekov um treba da dobije svoje utemeljenje, obrazloženje i oblikovanje kao nesumnjiva i opšte-obavezujuća izvesnost". ${ }^{18}$ Prema Hajdegerovom sudu, upravo ovakav primat uma ono je što će Kant staviti u centar svog kritičkog poduhvata.

$\mathrm{Na}$ ovom mestu vredi upitati - kako stvari onda stoje sa Baumgartenom estetičarom? Hajdeger o tome kaže da je Baumgarten, pored metafizike, „načinio - u opštim crtama oblikovanja vladavine čistog uma pokušaj da umetnost $\mathrm{i}$ odnos prema umetnosti, tj. prema tadašnjem shvatanju: ukus, podvede pod principe uma. [...] Onako kako se mišljenje u logici stavlja pod principe uma, tako je potrebno i jedno umsko učenje o onome čulnom, jedna logika toga čulnog - logika $\alpha \ddot{l} \sigma \theta \eta \sigma \check{\iota} \varsigma$-a" ${ }^{19} \mathrm{U}$ ovoj oceni Hajdeger ne greši, jer Baumgartenova estetika zaista jeste zamišljena kao pokušaj da se u domenu senzitivnosti učini isto ono što je logikom već učinjeno u području (čistog) razuma. Štaviše, Baumgartenova estetika nesumnjivo je iskivana uz značajno oslanjanje na pretpostavljenu analogiju viših i nižih saznajnih moći, odnosno logike i estetike. ${ }^{20}$

Takođe, interesantno je primetiti da Hajdeger ovde, izgleda, deli poziciju većine interpretatora Baumgartenove misli - bar onu koja je bila dominantna u nemačkoj filozofiji kraja XIX i tokom XX veka - da je u centru njegove estetike upravo pitanje o umetnosti. Ipak, Hajdeger dodaje $\mathrm{i}$ značajan detalj, umetnost - ali $i$ odnos prema umetnosti. Uprkos ovoj podudarnosti, čini se da bi bilo previše odvažno tvrditi da je Hajdeger bio naročito upoznat sa ovom tradicijom tumačenja Baumgartena, najpre zbog

\footnotetext{
${ }^{17}$ Ibid., str. 112.

18 Ibid.

${ }^{19}$ Ibid., str. 107.

${ }^{20}$ Up. Baumgarten, A. G., Ästhetik I, Felix Meiner Verlag, Hamburg, 2007, str. 11, 405; Baumgarten, A. G., Filozofske meditacije o nekim aspektima pesničkog dela, BIGZ, Beograd, 1985, str. 85.
} 
toga što o tako nečemu nemamo podataka, a potom i zbog toga što interpretacije Baumgartena nikada, pa ni u Hajdegerovo vreme, nisu zauzimale naročito prominentno mesto $\mathrm{u}$ istoriji estetike (ili filozofije). Pre bismo dobro učinili ukoliko bismo ovakav pogled na Baumgartenovu estetiku pripisali Hajdegerovim sopstvenim interesima, odnosno činjenici da od svih tradicionalno estetičkih pitanja - lepote, umetnosti i estetskog iskustva - upravo pitanje umetnosti za Hajdegera ima odlučujući značaj. Pri tome je takođe važno primetiti da činjenica da su ova tri pitanja tradicionalno i tipično estetička počiva upravo na Baumgartenovom osmišljavanju estetike.

Drugim rečima, Hajdegerov sopstveni interes za umetnost kao centralno pitanje na kome bi trebalo da se odluči odnos između estetskog i filozofskog, smatramo, vodi i njegovu interpretaciju smisla Baumgartenovog projekta estetike. Navedeno ne u smislu da Hajdeger, eventualno, ne bi bio otvoren i za drugačije akcentuacije ovog projekta, već upravo u onom smislu $\mathrm{u}$ kom on uvek i pristupa tumačenju mislilaca tradicije - $\mathrm{s}$ obzirom na način na koji njihova misao govori savremenosti. Rečju, Hajdegera nikada, pa ni ovde, ne interesuje neka idealizovana istina Baumgartenove filozofije po sebi, budući da on smatra da bilo kakva istina tradicionalnih pozicija uopšte može da se pokaže samo za nas, savremene, odnosno u dijalogu između tradicije i savremenosti. Ukoliko prethodni citat čitamo u ovom ključu, moramo konstatovati da je prvobitni projekt estetike za nas danas živ i otvoren upravo kao specifična - metafizička - tematizacija umetnosti.

Sve navedeno vraća nas nazad ideji prevladavanja estetike; u pitanju je ključni aspekt prevladavanja metafizike, kako Hajdeger tvrdi u Prilozima filozofiji. ${ }^{21}$ Naime, ukoliko su Hajdegerova razračunavanja sa tradicijom filozofije u njegovim poznim radovima inače vođena pod zastavom ideje prevladavanja, te ukoliko je teza o prevladavanju estetike pri tome posebno istaknuta, nije li za očekivati da se takvo šta tiče upravo prve od svih estetika - one Baumgartenove? Ipak, to nije slučaj; prevladavanje estetike nije tematski vezano za Baumgartena, niti je u okviru ovog projekta Baumgartenu dodeljeno naročito važno mesto. Štaviše, kao što smo već pomenuli, Hajdeger o Baumgartenu skoro da i ne govori. Uprkos tome,

${ }^{21}$ Up. Heidegger, M., Prilozi filozofiji, str. 408-409. 
nekoliko opaski koje Hajdeger upućuje na račun osnivača estetike, a posebno način na koji on to čini, pokazuju nam suprotno: prvi projekat estetike jeste bitno vezan za prevladavanje estetike.

Komentarišući da je upravo Baumgarten ovoj disciplini dao njeno ime - kao i to da se Kant protivio upotrebi tog pojma - Hajdeger nastavlja: „To je nešto što sadrži više od puke prigodnosti jednog naziva, to je pre jedna činjenica koja može da se pojmi samo iz novovekovne metafizike, i koja je bila odlučujuća ne samo za izlaganje suštine umetnosti, nego uopšte za položaj umetnosti u tubitku epohe Getea, Šilera, Šelinga i Hegela" [kurzivom istakla U. P.]. ${ }^{22}$ Kako vidimo, estetika nije tek bilo kakav filozofski projekat - ona je neposredno vezana za metafiziku novovekovlja, čak u toj meri da se bez razumevanja novovekovne metafizike, kao i bez razumevanja veze metafizike i estetike, ona zapravo ni ne može pojmiti. Za sad možemo zaključiti: novovekovna metafizika osnov je Baumgartenove a čini se i svake buduće - estetike. Shodno tome, važi i sledeće: ako je potrebno razračunati se sa estetikom, onda će to nužno voditi ka suočavanju i razračunavanju sa (novovekovnom) metafizikom. Prevladavanje estetike, tako, mora imati veze sa prevladavanjem (novovekovne) metafizike.

Ipak, nije li ovakav zaključak isuviše trivijalan? Za očekivati je od duha sistema XVIII veka, a posebno od autora kao što je Baumgarten, kog i sam Hajdeger ističe kao metafizičara od ranga, da metafiziku postavi kao osnov, a ostale filozofske discipline, pa i estetiku, kao one koje su na tom osnovu utemeljene? Nije li, stoga, trivijalno konstatovati da estetika zavisi od metafizike? Sa druge strane, nije li ovakav zaključak, makar i ne bio trivijalan, rezervisan za odnos novovekovne metafizike i estetike, kako i Hajdeger, čini se, sugeriše?

Odgovori na sva ova pitanja moraju biti odrični. Naime, ističući vezu metafizike i estetike, Hajdeger uopšte ne cilja na neki spoljašnji poredak znanja i disciplina shodno njihovoj opštosti, već, kako je i ranije pomenuto, on cilja na to da način na koji se misli u metafizici - a to znači povodom pitanja o bivstvovanju - ostaje na snazi i u estetici i određuje je. To, dakle, ne znači prosto da estetika unapred datu metafizičku strukturu stvarnosti razrađuje u jednom njenom delu, naime onom koji se tiče tačno

${ }^{22}$ Хајдегер, М., Питање о ствари, str. 107. 
određenog i omeđenog regiona bića, poput umetničkih dela, lepih predmeta i slično. Za Hajdegera, navedeno znači da pitanja estetike nisu ontološki neutralna, već da ona samim svojim oblikom i načinom postavljanja utiru put tačno određenom i metafizikom zacrtanom razumevanju bivstvovanja. Otuda će i svi mogući odgovori na takva pitanja, ma kako bili međusobno različiti, biti jednako ograničeni na isto to razumevanje bivstvovanja.

Shodno tome, nije trivijalno istaći da se smisao estetike ne može razumeti ukoliko se ne obrati pažnja na vezu metafizike i estetike. Naprotiv, upućivanje na taj problem zapravo je Hajdegerov način da pita o tome kako se u estetici tipično misli, koji je njen način misaonog postupanja - pitanje koje, po pravilu, izostaje iz skoro svih estetičkih projekata, jer se oni, nakon zasnivanja discipline, postavljaju tako da se estetički manir filozofskog mišljenja uzima kao već uspostavljen i dat. Pri tome, naravno, ne mislimo na metodologiju različitih estetika, koja može biti, na primer, fenomenološka ili strukturalistička ili bilo koja druga. U tom pogledu se različiti estetički projekti nesumnjivo razlikuju, ali, ipak, to ne znači da je isticanjem metodoloških okvira išta rečeno o načinu estetičkog mišljenja koje je artikulisano tim metodskim postupcima. Hajdeger bi, zapravo, rekao da različite metodologije ovde ne menjaju na stvari, jer sve prećutno dele iste pretpostavke o estetici.

Čini se da je jedna od ključnih takvih pretpostavki upravo samorazumljivost postojanja predmeta obrade estetike, bilo da se kao istaknuto bira prirodno lepo biće ili umetničko delo. Oni su, nekako, već tu i dati, te se, onda, ta njihova datost uzima kao nešto jasno samo po sebi, a unapred otvoreno za filozofsko razmatranje i njemu transparentno. O tome Hajdeger govori u Izvoru umetničkog dela upravo u vezi sa pojmom stvari: „Ako dela pogledamo u njihovoj nedirnutoj realnosti i pri tom sebe ne zavaravamo, tada se pokazuje: dela su tako prirodno prisutna kao i ostale stvari. (...) Sva dela imaju taj karakter stvari". ${ }^{23}$ Utoliko se pokazuje jasnijim i zašto se komentari o Baumgartenu javljaju u predavanju naslovljenom Pitanje o stvari.

Rečju, na delu je ontološka pretpostavka, i to u svom metafizičkom ruhu: postoje neka bića, takva koja se od ostalih bića razlikuju po svojim

${ }^{23}$ Хајдегер, М., „Извор уметничког дела”, str. 8-9. 
estetskim svojstvima i karakteristikama. Otuda se estetika bavi upravo njima, a sav njen napor usmeren je na istraživanje tih svojstava kao differentia specifica određene oblasti postojećeg u odnosu na druge takve oblasti; tek tu dolazi do razlika u estetičkim pozicijama. U takvoj slici, odnos filozofije i umetnosti, na primer, postaje činjenica, te se tako previđa za Hajdegera osnovno pitanje - da li je, uprkos tome što su umetnička dela de facto data i prisutna, slučaj umetnosti uopšte dostupan i otvoren za filozofsko promišljanje? Može li filozofija, shodno onome što ona jeste, da stupi u odnos prema umetnosti, pa još u tom odnosu da se kao filozofija i ostvari?

Na prvi pogled, čini se da su i ova pitanja trivijalna: ne dokazuju li tomovi i tomovi estetičkih dela, kako onih nakon Baumgartena, tako i onih pre njega, koje takođe smatramo estetičkim, da je odnos filozofije i umetnosti davno uspostavljen? Iznova, iz Hajdegerove perspektive morali bismo da odreknemo trivijalnost ovom pitanju i pozitivnom odgovoru na njega koji se nameće. Hajdeger bi, zapravo, rekao da se filozofija kao estetika nikada zaista nije dotakla umetnosti, da je ona, govoreći o umetnosti, istu tretirala $\mathrm{s}$ obzirom na prethodno ocrtane metafizičke pretpostavke, a što je za posledicu imalo da se susret umetnosti i filozofije nikada i nije ostvario. Jednostavnije rečeno, filozofija je, prema Hajdegeru, uvek o umetnosti sudila shodno samoj sebi (odnosno metafizici), a ne spram umetnosti ili umetničkih dela; ona, sve vreme, razgovara sama sa sobom. Kako je već nagovešteno, za Hajdegera ovakav opis situacije ne važi samo za novovekovlje i Baumgartenovu estetiku, već za sva filozofska promišljanja koja, povratno, razumemo kao estetička, još od antike. Otuda on i tvrdi da je estetika stara koliko i logika, igrajući se implicitno sa Baumgartenovom postavkom discipline. ${ }^{24}$

Isticanje novovekovne metafizike i estetike, tako, ima funkciju odlikovanog primera, ma koliko da Hajdeger ne razvija mnogo analizu istih. Razlog naglašavanju novovekovlja je, verujemo, Hajdegerovo ubeđenje, koje on jasno izlaže u pogovoru Izvora umetničkog dela, da je upravo novovekovni način mišljenja o umetnosti i estetskom taj koji ponajviše određuje naše savremene pozicije. Centralni novovekovni pojam metafizičkog karaktera, a estetičke provinijencije, tako je pojam doživljaja:

${ }^{24}$ Uр. Хајдегер, М., Увод у метафизику, str. 120. 
„Estetika uzima umetničko delo kao predmet, i to kao predmet al̈ $\theta \eta \sigma l \varsigma$-a, čulnog razabiranja u širokom smislu. Danas se to razabiranje naziva doživljajem”. ${ }^{25}$ Takođe i: „Doživljaj je element koji je merilo ne samo za uživanje u umetnosti, već i za umetničko stvaranje. Sve je doživljaj”. ${ }^{26} \mathrm{U}$ predavanju Doba slike sveta iz 1938. godine on dodaje: „umetničko delo postaje predmet doživljaja, pa se umetnost smatra izrazom čovekovog života". 27

Kako vidimo iz prvog citata, određenje estetike iz Izvora jasno upućuje na Baumgartena iako on nije imenovan; štaviše, jasno je da ovi stavovi odgovaraju već navedenim o izboru imena estetike koje nije slučajno. Sada je jasno i zašto je tako: odabirom imena estetika, Baumgarten se odlučuje da ovu disciplinu utemelji u području čulnog razabiranja $u$ širokom smislu, a time se dalje opredeljuje i način na koji se estetički zahvata umetničko delo - ono je, dakle, predmet takve čulnosti. Štaviše, u Pitanju o stvari on jasno kaže da je izbor imena, kao signal metafizičkog porekla i karaktera estetike, činjenica „odlučujuća ne samo za izlaganje suštine umetnosti, nego uopšte za položaj umetnosti u tubitku epohe Getea, Šilera, Šelinga i Hegela" [kurzivom istakla U. P.]. ${ }^{28}$ Suština umetnosti kod Baumgartena je, stoga, takođe metafizički mišljena.

Navedeno odgovara jednoj od tradicionalnih predrasuda o stvari, koje Hajdeger takođe navodi i kritikuje u Izvoru: reč je o stvari kao jedinstvu raznovrsnosti onoga što je čulno dato. ${ }^{29}$ Kako je pomenuto, suprotstavljanje stvari i dela u Izvoru upravo je primer raskrivanja skrivenih metafizičkih pretpostavki u osnovi našeg savremenog odnosa prema umetnosti. Sada je jasno: način na koji se Baumgartenova estetika pokazuje metafizičkom tiče se upravo suštine umetnosti, a to se pokazuje na primeru umetničkog dela, koje se estetički ne zahvata kao delo, već kao stvar - predmet čulnog

${ }^{25}$ Хајдегер, М., „Извор уметничког дела”, str. 57.

26 Ibid.

27 Хајдегер, М., „Доба слике света”, у: Шумски путеви, Плато, Београд, 2000, str. 60.

${ }^{28}$ Хајдегер, М., Питање о ствари, str. 107.

${ }^{29}$ Up. Ibid., str. 13-15; von Hermann, F.-W., Die zarte, aber helle Differenz. Heidegger und Stefan George, Vittorio Klostermann, Frankfurt am Mein, 1999, str. $10,14$. 
razabiranja. Kao takva, prva estetika zapravo utvrđuje metafizičke tendencije tradicionalnog pristupa umetnosti prikrivajući ih $\mathrm{u}$ drugom obliku - u vidu nove i od metafizike različite discipline. Sama postavka Baumgartenove estetike, iako smera na zasnivanje discipline o unutrašnjim zakonitostima senzitivnosti analogne logici, posledično uspostavlja razumevanje umetničkog dela po modelu stvari, u duhu metafizike. Pitanje o stvari je, dakle, u srži Baumgartenove estetike, čak i ako on toga nije bio svestan.

Konačno, ako je tako, onda je Baumgartenova estetika metafizička u mnogo značajnijem smislu nego što je to puko njeno disciplinarno utemeljenje u području metafizike. Ona je, mogli bismo reči, suštinski metafizička; isto, po Hajdegeru, očigledno važi i za svaku drugu estetiku. Ili, drugačije rečeno, estetički način mišljenja, za koji Baumgarten nastoji da se izbori i da ga istakne kao nov i specifičan, zapravo je samo jedna iteracija vladajućih oblika filozofije i ne odstupa radikalno od njih. Stoga je estetiku neophodno prevladati: kao nosilac nivelacije ontološke diferencije, ona ne nudi model valjanog filozofskog odnosa prema umetnosti. $U$ tom pogledu Baumgarten se ispostavlja jednako značajnim estetičarom kao i metafizičarom: njegova estetika je, zapravo, oblik uobičajene estetike.

\section{ZAKLJUČNA RAZMATRANJA}

Na samom kraju naših razmatranja vraćamo se temi prevladavanja estetike i tvrdimo: njen smisao, bar u jednom svom kraku, podrazumeva razračunavanje sa naslagama tradicije estetičkog mišljenja u ime oslobađanja novog prostora za odnos filozofije i umetnosti, kao i filozofije i lepote i slično. Ovo bi, prirodno, podrazumevalo i razračunavanje sa svim pretpostavkama zajedničkim tradicionalnom estetičkom mišljenju. Da se zadržimo na primeru koji smo i prethodno izdvojili: ako je samorazumljivost otvorenosti umetnosti za filozofski pogled bila jedna od ključnih karakteristika tradicije, sada bi upravo to moralo biti dovedeno u pitanje. Dakle, sada bismo, zajedno sa Hajdegerom, morali zaključiti da odnos filozofije i umetnosti treba ne samo preispitati i iznova promisliti, već i da se treba zapitati da li filozof uopšte može da misli o umetnosti, te ako može kako? 
Hajdegerov odgovor na ovo pitanje dobro je poznat: u svojoj poznoj filozofiji on će postojano insistirati na značaju filozofskog odnosa prema umetnosti, u toj meri da će umetnost postati jedna od za njega najznačajnijih tema. Ipak, to insistiranje ne podrazumeva da se unapred zna kako se sa umetnošću tu treba postupati. Naprotiv, jedina smernica koju Hajdeger u tom pogledu daje je formalna naznaka dijaloga pevanja i mišljenja, odnosno umetnosti i filozofije. Takav dijalog, očigledno, zamišljen je kao protivotrov tradicionalnom filozofskom monologu povodom umetnosti i domena estetskog uopšte, ali on, zapravo, ne govori mnogo više od toga. Kao formalna naznaka, ova formulacija ima za cilj samo da ukaže na određeni način misaonog držanja koji je u datoj situaciji primereno zauzeti, a on sugeriše izmenu hijerarhijskog odnosa filozofije i umetnosti (ili metafizike i estetike) - pri čemu je filozofija još od Platona nadređena umetnosti - ka njihovom horizontalnom koordiniranju, odnosno ravnopravnom dijalogu. ${ }^{30}$

Ako bismo išli korak dalje, takođe bismo mogli reći da ova formalna naznaka sugeriše $\mathrm{i}$ da se u takvom dijalogu filozofija mora postaviti fenomenološki, odnosno da ona mora dopustiti umetnosti da se pokaže kao fenomen - dakle, polazeći od sebe same, i da takvo njeno samo-pokazivanje filozofija mora da uvaži, da bi se dijalog uopšte i desio. Ipak, to nije sve: umesto da razvijamo ovaj korak dalje, radije bismo se vratili korak unazad i konstatovali da celokupna situacija dijaloga pevanja i mišljenja pretpostavlja datost umetnosti, odnosno umetničkih dela, za mišljenje. S obzirom na to da u ovaj dijalog mi već stupamo sa pozicija filozofije, učešće filozofije u njemu nije posebno iznenađujuće, ali je datost umetnosti nešto što mora biti uvaženo kao iznenađenje, slučaj, događaj, a nikako kao unapred uračunata i očekivana mogućnost.

Rečju, da bi do ovog dijaloga uopšte došlo, umetnost mora, sa svoje strane, da u njemu učestvuje - a to znači da umetnost mora biti data, odnosno da se dijalog mora voditi povodom i u okružju nekog konkretnog umetničkog dela. Ovo je postupak koji Hajdeger nesumnjivo sprovodi u svojim radovima, jer tu nikada nije reč o nekom apstraktnom pojmu umetnosti, već uvek o konkretnom delu sa kojim se filozof susreće, te

30 Up. von Hermann, F.-W., Wege ins Ereignis, Zu Heideggers Beiträgen zur Philosophie, Vittorio Klostermann, Frankfurt am Mein, 1994, str. 224. 
polazeći od tog susreta dalje misli. Ako se na osnovu takvog postupka Hajdeger i otisne ka nekim opštijim tezama, on to ne čini na tradicionalni način, apstrahovanjem do suštine umetnosti, već za takav gest bira druge i netipične puteve. Osnovni napor u tom poduhvatu je, dakle, permanentna otvorenost dijaloga pevanja i mišljenja: ako ta formulacija išta treba da znači, ona se mora iznova i iznova stavljati u pogon, iznova i iznova izvršavati i sprovoditi u delo prilikom svakog susreta sa umetničkim delima.

U tom svetlu, konačno, možemo oceniti i pravi smisao Hajdegerovih komentara o Baumgartenu. Naime, ako je uvažavanje datosti umetničkog dela preduslov ispravnog odnosa filozofije i umetnosti, onda se ona ne sme podrazumevano obremeniti tradicionalnim predkoncepcijama. U ovom slučaju najveća opasnost preti od razumevanja umetničkog dela kao stvari, odnosno od zahvatanja njegove datosti na način tradicionalne metafizike, umesto fenomenološki - kao fenomena. Kako smo videli, iako Baumgarten tu tezu ne zastupa otvoreno, njegova estetika je u celini, bar prema Hajdegeru, vođena upravo pitanjem o stvari. U tom smislu za Baumgartena se ne samo umetničko delo, već i bilo koji estetski relevantan predmet u konačnom zahvata kao stvar.

Takođe, iako osnivač estetike, Baumgarten se u tom pogledu ne razlikuje bitno od bilo kog drugog tradicionalnog mislioca posvećenog estetičkoj problematici; utoliko je njegova estetika, ma koliko istorijski radikalna i nova, zapravo osnovni oblik uobičajene estetike. Projekat zasnivanja estetike, stoga, za Hajdegera ne predstavlja nikakvu emancipaciju filozofskog mišljenja o umetnosti, već samo kristalizaciju njegovih već postojećih tendencija. Osvrt na Baumgartena, međutim, utoliko je značajniji: Hajdegerova kritika znači da tradicija nije imala snage da se u pogledu svog odnosa spram umetnosti razračuna sa samom sobom, čak ni kada je to pokušala. Navedeno nije samo znak kritike tradicije, već i upozorenje za savremenu misao: problem umetnosti očigledno zahteva veću pažnju i posvećenost nego što se to na prvi pogled čini. Dijalog pevanja i mišljenja, stoga, mora se sprovoditi naporedo sa prevladavanjem estetike. 


\section{LITERATURA}

Baumgarten, A. G., Filozofske meditacije o nekim aspektima pesničkog dela, BIGZ, Beograd, 1985.

Baumgarten, A. G., Ästhetik I, Felix Meiner Verlag, Hamburg, 2007.

Baumgarten, A. G., Metaphysica. Metaphysik, Frommann-Holzboog Verlag, Stuttgart, 2011.

Heidegger, M., „Seminar in Le Thor 1969”, in: Seminare, GA 15, Vittorio Klostermann, Frankfurt am Mein, 1986.

Heidegger, M., Bitak i vrijeme, Naprijed, Zagreb, 1988.

Хајдегер, М., Увод у метафизику, Еидос, Врњачка Бања, 1997.

Хајдегер, М., „Ствар”, у: Предавања и расправе, Плато, Београд, 1999.

Хајдегер, М., „Доба слике света”, у: Шумски путеви, Плато, Београд, 2000.

Хајдегер, М., „Извор уметничког дела”, у: Шумски путеви, Плато, Београд, 2000.

Heidegger, M., Prilozi filozofiji. Iz dogođaja, Naklada Breza, Zagreb, 2008.

Хајдегер, М., Питање о ствари. О Кантовом учењу о трансценденталним начелима, Плато, Београд, 2009.

von Hermann, F.-W., Wege ins Ereignis, Zu Heideggers Beiträgen zur Philosophie, Vittorio Klostermann, Frankfurt am Mein, 1994.

von Hermann, F.-W., Die zarte, aber helle Differenz. Heidegger und Stefan George, Vittorio Klostermann, Frankfurt am Mein, 1999.

Kockelmans, J. J., On the truth of Being, Reflections on Heidegger's later philosophy, Indiana University Press, Bloomington, 1984.

Mirbach, D., 'Einführung zur fragmentarischen Ganzheit von Alexander Gottlieb Baumgartens Aesthetica $(1750 / 1758)^{\circ}$, in: Baumgarten, A. G., Ästhetik I, Felix Meiner Verlag, Hamburg, 2007.

Poppe, B., Alexander Gottlieb Baumgarten. Seine Bedeutung und Stellung in der Leibniz-Wollfische Philosophie und seine Beziehungen zu Kant, Buchdruckerei Robert Noske, Borna-Leipzig, 1907. 


\title{
UNA POPOVIĆ \\ University of Novi Sad, Faculty of Philosophy HEIDEGGER ON BAUMGARTEN
}

\begin{abstract}
This paper brings forth an interpretation of a few Heidegger's comments on Baumgarten, presented in his lecture The Question Concerning the Thing. The analysis shows Heidegger's focus on the relation between metaphysics and aesthetics in Baumgarten, and also that Baumgarten's foundation of aesthetics is related to modern understanding of a being as a thing and as an object of perception. The results imply a very important role of Heidegger's critique of Baumgarten in his project of overcoming of aesthetics. Also, they allow for an insightful interpretation of some of the key aspects of Heidegger's philosophy of art.
\end{abstract}

Keywords: Heidegger, Baumgarten, aesthetics, thing, overcoming

Primljeno: 22.2.2021.

Prihvaćeno: 3.5 .2021$. 
